\title{
PENINGKATAN HASIL BELAJAR IPA DENGAN METODE TEAMS ASSISTED INDIVIDUALIZATION
}

\author{
Gamar Al Haddar', Ayu Novita ${ }^{2}$ \\ Universitas Widya Gama Mahakam Samarinda ${ }^{1,2}$ \\ gamar@uwgm.ac.id ${ }^{1}$
}

\begin{abstract}
This study aims to improve the learning outcomes of science through cooperative learning methods of the Teams Assisted Individualization type. In grade IVA students at SD10 010 Sungai Kukung in the 2018/2019 school year. This type of research is classroom action research with 34 research subjects. Data collection techniques used in this study were Observation, Test and Documentation. This research was conducted in 3 cycles and each cycle consisted of 2 meetings, each cycle consisting of four stages, namely: Planning, Implementation, Observation, and Reflection. The results showed that there was an increase in each cycle with the percentage in cycle I $32.35 \%$ then increased in cycle II to $58.82 \%$ and increased again in cycle III to $94.11 \%$. Conclusions, while the results of the value of skills and attitude values that include the value of social attitudes and spiritual attitudes also experience an increase in each aspect. Thus the Teams Assisted Individualization Method can improve student learning outcomes in Natural Sciences.
\end{abstract}

Keywords: Teams Assisted Individualization Method, Learning Outcomes

\begin{abstract}
Abstrak: Penelitian ini bertujuan untuk meningkatkan hasil belajar IPA melalui metode pembelajaran kooperatif tipe Teams Assisted Individualization. Pada siswa kelas IVA SD Negeri 010 Sungai Kunjang tahun pelajaran 2018/2019. Jenis penelitian ini adalah penelitian tindakan kelas dengan subyek penelitian yakni, 34 siswa. Teknik pengumpulan data yang digunakan dalam penelitian ini adalah Observasi, Tes dan Dokumentasi. Penelitian ini dilaksanakan dalam 3 siklus dan setiap siklus terdiri dari 2 kali pertemuan, masing-masing siklus terdiri dari empat tahap, yaitu : Perencanaan, Pelaksanaan, Observasi, dan Refleksi. Hasil penelitian menunjukkan bahwa ada peningkatan pada setiap siklusnya dengan presentase pada siklus I 32,35\% kemudian meningkat di siklus II menjadi 58,82\% dan meningkat kembali di siklus III menjadi 94,11\%. Simpulan, Sedangkan hasil dari nilai keterampilan dan nilai sikap yang meliputi nilai sikap sosial dan sikap spiritual juga mengalami peningkatan pada tiap aspeknya. Dengan demikian Metode Teams Assisted Individualization dapat meningkatkan terhadap hasil belajar IPA siswa.
\end{abstract}

Kata Kunci: Metode Teams Assisted Individualization, Hasil Belajar

\section{PENDAHULUAN}

Sekolah dasar adalah jenjang yang paling dasar pada pendidikan formal di Indonesia. Sekolah Dasar ditempuh 6 tahun dimulai dari kelas 1 hingga kelas 6. Pendidikan Sekolah Dasar yaitu pendidikan anak berusia 7 hingga 13 tahun Sekolah Dasar merupakan pendidikan tingkat dasar dan berkembang sesuai dengan potensi daerah serta sosial budaya masyarakat setempat. Berdasarkan undang-undang dasar 1945, pendidikan Sekolah Dasar merupakan upaya mencerdaskan serta mencetak kehidupan bangsa yang bertaqwa, cinta tanah air, terampil, kreatif, berbudi pekerti yang santun serta mampu menyelesaikan permasalahan di lingkungannya.

Sementara itu Trianto (2014) menyebutkan bahwa model-model pembelajaran yang mengaitkan aktivitas pembelajaran menjadi lebih relevan. Dalam model pembelajaran terdapat pula berbagai macam metode pembelajaran. Metode ini dapat digunakan dalam proses pembelajaran yang dapat membuat pembelajaran 
menjadi lebih bervariasi serta lebih menarik untuk siswa.

Di dalam kelas, guru juga dapat tampil sebagai sosok yang mampu membuat siswa berpikir berbeda. Guru memberikan berbagai pertanyaan yang jawabannya tidak sekedar terkait dengan fakta ya atau tidak. Seoran guru di kelas dapat memberikan pertanyaan kepada siswa yang tentunya memerlukan jawaban kreatif, imajinatif dan sintesis.

Sebaliknya, dengan otoritasnya di kelas yang begitu besar, seorang guru tidak menutup kemungkinan akan tampil sebagai sosok yang membosankan dan tidak mampu menjadi idola bagi siswa. sebagai guru professional guru harus dapat menggunakan berbagai macam metode pembelajaran. Berdasarkan observasi yang dilakukan peneliti sebagai observer di kelas IV SD Negeri 010 Sungai Kunjang, didapatkan data bahwa hasil belajar IPA siswa masih belum mencapai nilai yang diinginkan sesuai KKM. Hal ini dapat dilihat dari nilai rata-rata hasil belajar siswa, hanya 64,66. Nilai rata-rata ini masih dibawah standar ketuntasan belajar mengajar (SKBM) yaitu 70 .

Model pembelajaran kooperatif merupakan model pembelajaran yang mengacu pada aktivitas pembelajaran kelompok. Disusun atas prinsip bahwa pembelajaran didasarkan pada perubahan informasi secara sosial di antara kelompok pembelajaran yang di dalamnya setiap pembelajar bertanggung jawab dengan pembelajarannya sendiri. Setiap anggota kelompok didorong dapat meningkatkan pembelajaran anggota yang lain (Huda, 2013).

Hasil penelitian yang dilakukan
oleh Slavin menyatakan bahwa penggunaan pembelajaran kooperatif meningkatkan prestasi belajar. serta meningkatkan hubungan sosial, menumbuhkan sikap toleransi dan menghargai pendapat orang lain. Pembelajaran kooperatif dapat bermanfaat untuk memenuhi kebutuhan siswa dalam berpikir kritis, memecahkan masalah serta mengintegritaskan pengetahuan dengan pengalaman (Rusman, 2011).

Metode pembelajaran kooperatif tipe Teams Assisted Individualization merupakan salah satu metode pembelajaran yang dapat digunakan untuk meningkatkan hasil belajar siswa. metode pembelajaran kooperatif tipe Teams Assisted Individualizatio ini mengharuskan siswa untuk aktif dalam kegiatan pembelajaran dan metode pembelajaran kooperatif tipe Teams Assisted Individualization ini menggabungkan pembelajaran kooperatif dengan pembelajaran individual. Adapun keunggulan dari pembelajaran ini adalah siswa dituntut untuk mengerjakan tugas yang diberikan oleh guru secara individual kemudian tugas tersebut dibawa kekelompok masing-masing dan teman satu kelompok saling memeriksa pekerjaan teman sekelompoknya.

Berdasarkan permasalahan di atas maka peneliti tertarik meneliti tentang Peningkatan Hasil Belajar IPA dengan Metode Teams Assisted Individualization pada Siswa Kelas IV SDN 010 Sungai Kunjang Samarinda.

\section{LANDASAN TEORI \\ Hasil Belajar}

Hamalik (2014) menyatakan bahwa hasil belajar merupakan bukti bahwa bila individu telah belajar maka terjadinya perubahan tingkah laku pada individu tersebut, misalnya dari tidak tahu menjadi tahu, serta dari tidak mengerti menjadi mengerti". Sanjaya (2010) hasil belajar berkaitan dengan pencapaian dalam memperoleh kemampuan sesuai dengan tujuan khusus yang direncanakan. Hal ini menunjukkan bahwa hasil belajar 
berkaitan dengan kemampuan dan tujuan yang ingin dicapai.

Oemar (2014) mengemukakan hasil belajar sebagai terjadinya perubahan tingkah laku pada diri siswa yang dapat diamati dan diukur dalam bentuk perubahan pengetahuan, sikap, serta keterampilan. Sudjana (2014) mengatakan bahwa hasil belajar adalah kemampuan yang dimiliki siswa setelah menerima pengalaman belajarnya.

Berdasarkan pendapat di atas, dapat disimpulkan bahwa hasil belajar merupakan hasil suatu tindakan belajar, biasanya ditunjukkan dengan nilai tes dan adanya perubahan tingkah laku siswa, antara lain pengetahuan, perkembangan tiap peserta didik.

\section{Metode Teams Assisted Individualization}

Metode pembelajaran Teams Assisted Individualization pertama kali diprakarsai oleh Robert E.Slavin yang merupakan perpaduan antara pembelajaran kooperatif dengan pengajaran individu. Menurut (Slavin, 2016), Teams Assisted Individualization merupakan sebuah program pedagogik yang berusaha mengadaptasikan pembelajaran dengan perbedaan individual siswa secara akademik.

Menurut Shoimin (2014)

Teams Assisted Individualization memiliki dasar pemikiran yaitu untuk mengadaptasi pembelajaran terhadap perbedaan individual. Dalam hal ini berkaitan dengan kemampuan maupun pencapaian prestasi siswa. Dasar pemikiran dibalik individualisasi pembelajaran adalah para siswa memasuki kelas dengan pengetahuan, kemampuan dan motivasi yang sangat beragam. Ketika guru menyampaikan sebuah pelajaran kepada setiap kelompok, besar kemungkinan ada sebagian siswa yang tidak memiliki syarat kemampuan untuk memelajari pelajaran tersebut akan gagal memperoleh manfaat dari metode tersebut. Siswa lainnya mungkin sudah tahu materi itu atau bisa mempelajarinya dengan sangat cepat sehingga waktu pembelajaran yang dihabiskan bagi mereka hanya membuang waktu.

Dari pendapat di atas, dapat disimpulkan bahwa metode pembelajaran teams assisted individualization adalah metode yang memberikan kesempatan siswa untuk mencari jawaban tugas secara individu, kemudian bertukar pikiran dengan teman kelompok. Dengan demikian, diharapkan siswa mampu bekerja sama, saling membutuhkan dan saling menghargai pendapat.

\section{METODE PENELITIAN}

Penelitian yang dilakukan oleh peneliti ini merupakan Penelitian Tindakan Kelas (PTK).

Tempat penelitian ini dilaksanakan di SD Negeri 010 Sungai Kunjang yang berlokasi di Jalan M.Said Kelurahan Lok Bahu Kecamatan Sungai Kunjang. Subjek penelitian adalah siswa kelas IVA SDN 010 Sungai Kunjang yang berjumlah 34 siswa, terdiri dari 20 siswa laki-laki dan 14 siswa perempuan serta guru kelas. Penelitian ini dilaksanakan dalam 3 siklus. Setiap siklus terdiri dari $2 \mathrm{x}$ pertemuan dalam tiap pertemuan ada empat tahapan dalam penelitian tindakan kelas yaitu perencanaan tindakan, pelaksanaan tindakan, observasi dan refleksi. Adapun teknik pengumpulan datanya yakni observasi, tes dan dokumentasi.

Indikator keberhasilan yang menyatakan bahwa pembelajaran yang berlangsung selama penelitian tindakan kelas ini berhasil meningkatkan hasil bealajar siswa dan terjadi peningkatan rata-rata hasil belajar siswa pada tema cita-citaku subtema aku dan cita-citaku setiap siklus secara individu telah memperoleh $\geq 70$ sebagaimana Kriteria Ketuntasan Minimal (KKM), dan juga 
telah memenuhi peningkatan ketuntasan belajar siswa sebanayak $80 \%$ dengan kriteria baik.

\section{HASIL PENELITIAN}

Penelitian ini dilakukan di Sekolah Dasar Negeri 010 Sungai Kunjang yang beralamat di Jalan M.Said, Sungai Kunjang. Penelitian ini dimulai dari tanggal 08 April 2019 sampai dengan 08 Mei 2019. Kelas IVA adalah kelas yang digunakan untuk penelitian dengan perlakuan menggunakan metode pembelajaran Teams Assisted Individualization yang berjumlah 34 siswa. Pokok bahasan yang digunakan pada penelitian ini adalah IPA materi daur hidup hewan, hasil yang di ukur adalah hasil belajar dan sebagai alat ukurnya adalah soal evaluasi.

Sebelum pelaksanaan penelitian, terlebih dahulu peneliti menganalisis data nilai siswa sebelum penelitian yang berasal dari nilai akhir semester sebelumnya dan melakukan observasi oleh guru kelas IVA dengan didasarkan pada indikator-indikator tertentu yang dapat dilihat pada lampiran. Peneliti bertindak sebagai pengajar melakukan kegiatan belajar mengajar sesuai dengan rencana pelaksanaan pembelajaran (RPP) yang telah direncanakan.

Penelitian ini terdiri dari tiga siklus, setiap siklus terdiri dari dua kali pertemuan. Pada setiap akhir siklus diberikan tes untuk mengetahui kemampuan siswa, kemudian dianalisis untuk mengetahui sejauh mana peningkatan hasil belajar siswa per siklus, apabila permasalahan belum terselesaikan maka permasalahan tersebut akan diselesaikan ke siklus berikutnya. Analisis data dilakukan untuk memperoleh nilai hasil belajar siswa setiap siklus dan untuk mengetahui kemampuan guru dan siswa dalam proses pembelajaran kooperatif tipe Teams Assisted Individualization.
Nilai akhir hasil belajar siswa diperoleh dari rata-rata nilai tugas tema cita-citaku dan nilai hasil belajar tema cita-citaku setiap akhir siklus.

Secara garis besar hasil penelitian yang diperoleh dari penelitian ini adalah hasil observasi dan hasil belajar siswa. Adapun hasil penelitian pada setiap siklus dapat diuraikan sebagai berikut:

\section{Siklus I \\ Perencanaan}

Pada tahap ini, peneliti menyusun rencana-rencana yang akan dilakukan pada saat pembelajaran, seperti menentukan materi yaitu materi tentang daur hidup hewan, menyusun rencana pembelajaran, menyiapkan instrument observasi dan instrument tes, kemudian mempersiapkan daftar hadir dan daftar nilai. yang akan melaksanakan tindakan pada siklus I adalah peneliti. Guru kelas IV sebagai observer hadir dalam kelas saat siklus dilaksanakan

\section{Pelaksanaan Tindakan}

Pembelajaran Siklus I pada pertemuan pertama dilaksanakan pada hari Senin tanggal 08 April 2019, pertemuan kedua dilaksanakan pada hari Kamis tanggal 11 April 2019. Pertemuan pertama menjelaskan materi dan pertemuan kedua dilakukan tes akhir/evaluasi.

Pada tahap ini peneliti melakukan kegiatan pembelajaran dikelas seperti guru biasanya. Perbandingan nilai dasar sebelum diterapkan metode pembelajaran yang akan digunakan peneliti. Pelaksanaan ini dilakukan sesuai rencana pelaksanaan pembelajaran (RPP) yang telah disiapkan terlebih dahulu oleh peneliti sebelum mengajar, diawali dengan pembukaan dengan mengucapkan salam dan menanyakan kesiapan siswa untuk mengikuti pembelajaran IPA yang akan 
dilakukan, melakukan absensi kelas, menjelaskan metode pembelajaran yang digunakan, menyampaikan tujuan pembelajaran serta menyampaikan apersepsi mengenai materi.

Guru

melaksanakan

pembelajaran sesuai dengan tahapan metode pembelajaran Teams Assisted Individualization. Guru memberikan pengajaran secara singkat, siswa yang belum paham dipersilahkan untuk bertanya, kemudian guru memberikan lembar materi kepada siswa untuk mempelajari materi pembelajaran secara individu yang sudah disiapkan oleh guru. Selanjutnya, siswa mengerjakan latihan kemampuan yang terdapat di lembar materi secara individu.

Dengan bimbingan guru siswa diminta membentuk 5 kelompok, hasil belajar siswa secara individu diperiksa dalam kelompok, setiap anggota kelompok saling memeriksa jawaban teman satu kelompoknya, jika terdapat masalah yang tidak dapat diselesaikan dengan kelompoknya, dipersilahkan bertanya kepada guru. Selanjutnya, siswa dipersilahkan untuk mengerjakan tes formatif setelah itu kembali ke kelompok semula untuk mendiskusikan hasil jawaban mereka. Kemudian mereka mengerjakan tes unit secara individu yang diberikan oleh guru.

Pelaksanaan tindakan di lapangan, awalnya lebih dari sebagian siswa di kelas yang mendengarkan penjelasan atau informasi yang guru sampaikan. Ketika guru memberikan tes formatif dan tes unit hanya beberapa siswa mengerjakannya secara individu, sedangkan siswa lainnya mengerjakannya dengan dibantu oleh teman. Siswa sudah mulai dapat bekerja sama dengan teman kelompoknya dalam memeriksa dan memecahkan masalah setelah mengerjakan latihan kemampuan serta mengerjakan tes formatif yang diberikan oleh guru, walaupun ada beberapa siswa dari beberapa kelompok yang masih ribut, setelah melalui tes Hasil belajar tema cita-citaku. Kegiatan penutup, peneliti menanyakan kembali kepada siswa tentang hal-hal baru yang mereka pelajari pada hari tersebut. Siswa secara mandiri menceritakan kembali apa yang telah dipelajari. Kemudian kelas ditutup dengan berdoa dan salam penutup.

Berdasarkan hasil belajar diperoleh nilai rata-rata pada siklus I adalah 58,38 dengan presentase ketuntasan $32,35 \%$ dan presentase yang belum tuntas adalah 67,64\%. Hasil belajar pada siklus I belum memenuhi kriteria keberhasilan. Hasil belajar pada nilai keterampilan dalam menuliskan hasil diskusi siswa pada siklus I nilai Rata-rata adalah 62,94 dengan presentase $35,29 \%$ dan presentase yang belum tuntas adalah 64,70\%. Adapun nilai afektif siswa yakni dinilai dari sikap sosial dan sikap spiritual dari 34 siswa yang memiliki sikap sosial dikategorikan baik adalah 32 orang dan dikategorikan sangat baik adalah 2 orang. Sedangkan sikap spiritual dikategorikan baik adalah 19 orang dan dikategorikan sangat baik adalah 15 orang.

\section{Observasi}

Dalam tahap observasi peneliti melakukan kegiatan pengamatan kepada siswa menggunakan lembar soal dan lembar observasi siswa.

\section{Hasil Aktivitas Siswa}

Hasil observasi siswa secara keseluruhan berjalan dengan cukup baik, yang mana siswa mulai memperhatikan pada saat peneliti menjelaskan materi pelajaran. Namun secara keseluruhan masih perlu adanya perbaikan yang harus dilaksanakan pada siklus II. Pada aspek pemahaman siswa pada materi dan tugas yang diberikan dikategorikan cukup dengan presentase $69 \%$. Pada aspek kerjasama siswa dalam diskusi kelompok dikategorikan cukup 
dengan presentase $65 \%$. Pada aspek keaktifan yang mana siswa aktif dalam pembelajaran dan diskusi kelompok dikategorikan cukup dengan presentase $65 \%$. Pada aspek perhatian dan mengerjakan tugas yang diberikan siswa dikategorikan cukup dengan presentase $64 \%$.

\section{Hasil Aktivitas Guru}

Observasi pada aktivitas guru adalah menilai peneliti pada saat proses pembelajaran disiklus I yang dilakukan oleh guru kelas IVA. pada kegiatan mempersiapkan siswa dan melakukan apersepsi dilaksanakan dengan kategori baik. Pemahaman terhadap materi pembelajaran, pembagian kelompok dan membimbing siswa dalam melakukan diskusi dikategorikan baik. Menumbuhkan partisipasi aktif siswa dikategorikan baik. Adapun hal yang harus diperbaiki pada siklus I yaitu penguasaan kelas selama proses pembelajaran berlangsung agar tujuan pembelajaran dapat terlaksana dengan baik.

\section{Refleksi}

Setelah diadakan diskusi antara peneliti dengan observer kemudian menghasilkan kesepakatan yang nantinya akan ditindak lanjut pada siklus berikutnya, yaitu peneliti merapikan tulisan saat menulis di papan tulis, labih sering mengontrol siswa saat mengerjakan latihan kemampuan, lebih sering mengawasi siswa saat berlangsungnya diskusi kelompok. Berdasarkan data-data yang diperoleh pada tes evaluasi akhir menunjukkan bahwa adanya nilai rata-rata hasil belajar siswa pada siklus I adalah 58,38 dengan presentase $32,35 \%$. Siswa yang tuntas sebanyak 11 orang dengan presentase $32,35 \%$ dan siswa yang tidak tuntas sebanyak 23 orang dengan presentase $67,64 \%$. Dengan demikian belum tercapai indikator keberhasilan yakni $80 \%$ dan nilai ketuntasan KKM 70 .

Berdasarkan hasil observasi yang dilakukan masih terdapat kendala dalam menerapkan metode Teams Assisted Individualization. Siswa masih terbiasa belajar secara individu sehingga pada saat melakukan diskusi kelompok siswa masih kurang tertib. Selama proses pembelajaran berlangsung sebagian siswa lebih banyak bermain dan berbicara dengan teman kelompoknya. Oleh karena itu, perlu adanya perbaikan pada siklus berikutnya, untuk mengetahui perkembangan perilaku dan hasil belajar siswa menggunakan metode Teams Assisted Individualization.

\section{Siklus II}

\section{Perencanaan}

Pada siklus II ini RPP disusun dengan tujuan meningkatkan efektifitas yang telah dilakukan pada siklus II. RPP pada siklus II ini digunakan untuk dua kali pertemuan, yakni pertemuan pertama membahas materi tentang daur hidup hewan sedangkan pertemuan kedua dilakukan evaluasi akhir. Peneliti menyusun rencana yang dilakukan pada saat pembelajaran meliputi mempersiapkan alat-alat media yang digunakan, mempersiapkan instrument observasi dan instrument tes, mempersiapkan daftar hadir dan daftar nilai.

\section{Pelaksanaan}

Pembelajaran siklus II pada pertemuan pertama dilakukan pada hari senin 15 April 2019, pertemuan kedua siklus II dilaksanakan pada hari Rabu 17 April 2019. Setelah selesai pada tahap perencanaan kemudian dilaksanakan pada penelitian tindakan kelas siklus II dalam upaya meningkatkan kualitas pembelajaran dan memperbaiki kekurangan-kekuarang yang ada dalam pembelajaran siklus I. 
Berdasarkan hasil refleksi dan observasi pada siklus I dapat disimpulkan bahwa hal yang perlu diperbaiki pada penelitian selanjutnya yaitu pada siklus II antara lain : merapikan tulisan saat menulis di papan tulis, lebih sering mengontrol siswa saat mengerjakan latihan kemampuan, dan lebih sering mengawasi siswa saat berlangsungnya diskusi kelompok.

Materi pembelajaran yang disiapkan pada siklus II pertemuan pertama yaitu tentang daur hidup hewan. Dalam penentuan metode pembelajaran dalam RPP ini ada metode yang digabungkan yaitu metode ceramah, Tanya jawab, dan diskusi kelompok (metode Teams Assisted Individualization) dan metode pemberian tugas. Dan diharapkan dapat meningkatkan aktifitas dan hasil belajar siswa dalam pembelajaran Ilmu Pengetahuan Alam tentang daur hidup hewah.

Pada tahap ini peneliti melakukan kegiatan pembelajaran dikelas seperti guru biasanya. Perbandingan nilai dasar sebelum diterapkan metode pembelajaran yang akan digunakan peneliti. Pelaksanaan ini dilakukan sesuai rencana pelaksanaan pembelajaran (RPP) yang telah disiapkan terlebih dahulu oleh peneliti sebelum mengajar, diawali dengan pembukaan dengan mengucapkan salam dan menanyakan kesiapan siswa untuk mengikuti pembelajaran tema citacitaku yang akan dilakukan, melakukan absensi kelas, menjelaskan metode pembelajaran yang digunakan, menyampaikan tujuan pembelajaran serta menyampaikan apersepsi mengenai materi.

Guru

melaksanakan

pembelajaran sesuai dengan tahapan metode pembelajaran Teams Assisted Individualization. Guru memberikan pengajaran secara singkat, siswa yang belum paham dipersilahkan untuk bertanya, kemudian guru memberikan lembar materi kepada siswa untuk mempelajari materi pembelajaran secara individu yang sudah disiapkan oleh guru. Selanjutnya, siswa mengerjakan latihan kemampuan yang terdapat di lembar materi secara individu.

Dengan bimbingan guru siswa diminta membentuk 5 kelompok, hasil belajar siswa secara individu diperiksa dalam kelompok, setiap anggota kelompok saling memeriksa jawaban teman satu kelompoknya, jika terdapat masalah yang tidak dapat diselesaikan dengan kelompoknya, dipersilahkan bertanya kepada guru. Selanjutnya, siswa dipersilahkan untuk mengerjakan tes formatif setelah itu kembali ke kelompok semula untuk mendiskusikan hasil jawaban mereka. Kemudian mereka mengerjakan tes unit secara individu yang diberikan oleh guru.

Pelaksanaan tindakan di lapangan, awalnya lebih dari sebagian siswa di kelas yang mendengarkan penjelasan atau informasi yang guru sampaikan. Ketika guru memberikan tes formatif dan tes unit hanya beberapa siswa mengerjakannya secara individu, sedangkan siswa lainnya mengerjakannya dengan dibantu oleh teman. Siswa sudah mulai dapat bekerja sama dengan teman kelompoknya dalam memeriksa dan memecahkan masalah setelah mengerjakan latihan kemampuan serta mengerjakan tes formatif yang diberikan oleh guru, walaupun ada beberapa siswa dari beberapa kelompok yang masih ribut, setelah melalui tes Hasil belajar tema cita-citaku .Kegiatan penutup, peneliti menanyakan kembali kepada siswa tentang hal-hal baru yang mereka pelajari pada hari tersebut. Siswa secara mandiri menceritakan kembali apa yang telah dipelajari. Kemudian kelas ditutup dengan berdoa dan salam penutup. 
Berdasarkan hasil belajar diperoleh nilai rata-rata pada siklus II adalah 70,73 dengan presentase ketuntasan $58,82 \%$ dan presentase yang belum tuntas adalah $41,17 \%$. Hasil belajar pada siklus II belum memenuhi kriteria keberhasilan. Hasil belajar pada nilai keterampilan dalam menuliskan hasil diskusi siswa pada siklus II nilai Rata-rata adalah 7,11 dengan presentase $70,58 \%$ dan presentase yang belum tuntas adalah $29,41 \%$. Adapun nilai afektif siswa yakni dinilai dari sikap sosial dan sikap spiritual dari 34 siswa yang memiliki sikap sosial dikategorikan baik adalah 18 orang dan dikategorikan sangat baik adalah 16 orang. Sedangkan sikap spiritual dikategorikan baik adalah 16 orang dan dikategorikan sangat baik adalah 18 orang.

\section{Observasi}

Dalam tahap observasi peneliti melakukan kegiatan pengamatan kepada siswa menggunakan lembar soal dan lembar observasi siswa.

\section{Hasil Aktivitas Siswa}

Hasil observasi siswa secara keseluruhan berjalan dengan cukup baik, yang mana siswa mulai memperhatikan pada saat peneliti menjelaskan materi pelajaran. Namun secara keseluruhan masih perlu adanya perbaikan yang harus dilaksanakan pada siklus III. Pada aspek pemahaman siswa pada materi dan tugas yang diberikan dikategorikan baik dengan presentase $74 \%$. Pada aspek kerjasama siswa dalam diskusi kelompok dikategorikan baik dengan presentase $69 \%$. Pada aspek keaktifan yang mana siswa aktif dalam pembelajaran dan diskusi kelompok dikategorikan baik dengan presentase $75 \%$. Pada aspek perhatian dan mengerjakan tugas yang diberikan siswa dikategorikan baik dengan presentase $70 \%$.

\section{Hasil Aktivitas Guru}

Observasi pada aktivitas guru adalah menilai peneliti pada saat proses pembelajaran disiklus II yang dilakukan oleh guru kelas IVA. pada kegiatan mempersiapkan siswa dan melakukan apersepsi dilaksanakan dengan kategori baik. Pemahaman terhadap materi pembelajaran, pembagian kelompok dan membimbing siswa dalam melakukan diskusi dikategorikan baik. Menumbuhkan partisipasi aktif siswa dikategorikan baik. Adapun hal yang harus diperbaiki pada siklus II yaitu penguasaan kelas selama proses pembelajaran berlangsung agar tujuan pembelajaran dapat terlaksana dengan baik.

\section{Refleksi}

Setelah diadakan diskusi antara peneliti dengan observer kemudian menghasilkan kesepakatan yang nantinya akan ditindak lanjut pada siklus berikutnya, yakni: memusatkan perhatian siswa ke materi pembelajaran, menyimpulkan hasil diskusi siswa, memberikan contoh soal yang berhubungan dengan kehidupan seharihari dan membuat rangkuman terlebih dahulu sebelum menutup pembelajaran.

Berdasarkan data-data yang diperoleh pada tes evaluasi akhir menunjukkan bahwa adanya nilai ratarata hasil belajar siswa pada siklus II adalah 70,73 dengan presentase 58,82\%. Siswa yang tuntas sebanyak 20 orang dengan presentase $58,82 \%$ dan siswa yang tidak tuntas sebanyak 14 orang dengan presentase $41,17 \%$. Dengan demikian belum tercapai indikator keberhasilan yakni $80 \%$ dan nilai ketuntasan KKM 70.

Berdasarkan hasil observasi yang dilakukan masih terdapat kendala dalam menerapkan metode Teams Assisted Individualization. Siswa masih terbiasa belajar secara individu sehingga pada saat melakukan diskusi kelompok 
siswa masih kurang tertib. Selama proses pembelajaran berlangsung sebagian siswa ada yang bermain dan berbicara dengan teman kelompoknya. Oleh karena itu, perlu adanya perbaikan pada siklus berikutnya, untuk mengetahui perkembangan perilaku dan hasil belajar siswa menggunakan metode Teams Assisted Individualization.

\section{Siklus III}

\section{Perencanaan}

Perencanaan pada siklus III ini RPP disusun dengan tujuan dapat meningkatkan efektifitas pembelajaran yang telah dilakukan pada siklus II. RPP pada siklus III digunakan untuk dua kali pertemuan, yakni pertemuan pertama membahas materi tentang daur hidup hewan sedangkan pertemuan kedua dilaksanakan tes akhir atau evaluasi. Peneliti menyusun rencana yang akan dilakukan pada saat pembelajaran meliputi mempersiapkan alat-alat media yang digunakan, mempersiapkan instrument observasi dan instrument tes, mempersiapkan daftar hadir dan dafrar nilai.

\section{Pelaksanaan}

Pembelajaran Siklus III pada pertemuan pertama dilaksanakan pada hari Senin tanggal 22 April 2019, pertemuan kedua dilaksanakan pada hari Rabu tanggal 08 Mei 2019. Pertemuan pertama menjelaskan materi dan pertemuan kedua dilakukan tes akhir/evaluasi.

Pada tahap ini pelaksanaan ini dilakukan sesuai rencana pelaksanaan pembelajaran (RPP) yang telah disiapkan terlebih dahulu oleh penulis sebelum mengajar, diawali dengan pembukaan dengan mengucapkan salam dan menanyakan kesiapan siswa untuk mengikuti pembelajaran tema citacitaku yang akan dilakukan, melakukan absensi kelas, menjelaskan metode pembelajaran yang digunakan, menyampaikan tujuan pembelajaran serta menyampaikan apersepsi mengenai materi.

Berdasarkan hasil refleksi dan observasi pada siklus II dapat disimpulkan bahwa hal yang perlu diperbaiki pada penelitian selanjutnya yaitu pada siklus II antara lain : memusatkan perhatian siswa ke materi pembelajaran, menyimpulkan hasil diskusi siswa, memberikan contoh soal yang berhubungan dengan kehidupan sehari-hari dan membuat rangkuman terlebih dahulu sebelum menutup pembelajaran.

Guru melaksanakan pembelajaran sesuai dengan tahapan metode pembelajaran Teams Assisted Individualization. Guru memberikan pengajaran secara singkat, siswa yang belum paham dipersilahkan untuk bertanya, kemudian guru memberikan lembar materi kepada siswa untuk mempelajari materi pembelajaran secara individu yang sudah disiapkan oleh guru. Selanjutnya, siswa mengerjakan latihan kemampuan yang terdapat di lembar materi secara individu.

Guru membentuk 5

kelompok, hasil belajar siswa secara individu di periksa dalam kelompok, setiap anggota kelompok saling memeriksa jawaban teman satu kelompoknya, jika terdapat masalah yang tidak dapat diselesaikan dengan kelompoknya, dipersilahkan bertanya kepada guru. Selanjutnya, siswa dipersilahkan untuk mengerjakan tes formatif setelah itu kembali ke kelompok semula untuk mendiskusikan hasil jawaban mereka. Kemudian mereka mengerjakan tes unit secara individu yang diberikan oleh guru.

Pelaksanaan tindakan di lapangan, sudah banyak siswa di kelas yang mendengarkan penjelasan atau informasi yang guru sampaikan. Ketika guru memberikan tes formatif dan tes sudah terlihat siswa mengerjakan 
dengan fokus dan serius. Siswa sudah mulai dapat bekerja sama dengan teman kelompoknya dalam memeriksa dan memecahkan masalah setelah mengerjakan latihan kemampuan serta mengerjakan tes formatif yang diberikan oleh guru, setelah melalui tes Hasil belajar tema cita-citaku. Kegiatan penutup, peneliti menanyakan kembali kepada siswa tentang hal-hal baru yang mereka pelajari pada hari tersebut. Siswa secara mandiri menceritakan kembali apa yang telah dipelajari. Kemudian kelas ditutup dengan berdoa dan salam penutup.

Berdasarkan hasil belajar diperoleh nilai rata-rata pada siklus III adalah 80,14 dengan presentase ketuntasan $94,11 \%$ dan presentase yang belum tuntas $5,88 \%$. Hasil belajar pada siklus III sudah memenuhi kriteria keberhasilan yaitu $80 \%$. Hasil belajar pada nilai keterampilan dalam menuliskan hasil diskusi siswa pada siklus III nilai Rata-rata adalah 8,14 dengan presentase $91,17 \%$ dan presentase yang belum tuntas adalah $8,82 \%$. Adapun nilai afektif siswa yakni dinilai dari sikap sosial dan sikap spiritual pada siklus III semua siswa dikategorikan baik pada nilai sikap sosial. Sedangkan sikap spiritual dikategorikan baik adalah 8 orang dan dikategorikan sangat baik adalah 26 orang.

\section{Observasi}

Dalam tahap observasi peneliti melakukan kegiatan pengamatan kepada siswa menggunakan lembar soal dan lembar observasi siswa.

Hasil Aktivitas Siswa

Hasil observasi siswa secara keseluruhan berjalan dengan sangat baik, yang mana siswa telah memperhatikan pada saat peneliti menjelaskan materi pelajaran. Pada aspek pemahaman siswa pada materi dan tugas yang diberikan dikategorikan sangat baik dengan presentase $91 \%$.
Pada aspek kerjasama siswa dalam diskusi kelompok dikategorikan sanat baik dengan presentase $90 \%$. Pada aspek keaktifan yang mana siswa aktif dalam pembelajaran dan diskusi kelompok dikategorikan sangat baik dengan presentase 93\%. Pada aspek perhatian dan mengerjakan tugas yang diberikan siswa dikategorikan sangat baik dengan presentase $89 \%$.

\section{Hasil Aktivitas Guru}

Observasi pada aktivitas guru adalah menilai peneliti pada saat proses pembelajaran disiklus III yang dilakukan oleh wali kelas IV. pada kegiatan mempersiapkan siswa dan melakukan apersepsi dilaksanakan dengan kategori sangat baik. Pemahaman terhadap materi pembelajaran, pembagian kelompok dan membimbing siswa dalam melakukan diskusi dikategorikan sangat baik. Menumbuhkan partisipasi aktif siswa dikategorikan sangat baik.

\section{Refleksi}

Setelah diadakan diskusi antara peneliti dengan observer kemudian menghasilkan data-data yang diperoleh pada tes evaluasi akhir menunjukkan bahwa adanya nilai rata-rata hasil belajar siswa pada siklus III adalah 80,14 dengan presentase $94,11 \%$. Siswa yang tuntas sebanyak 32 orang dengan presentase $94,11 \%$ dan siswa yang tidak tuntas sebanyak 2 orang dengan presentase $5,88 \%$. Sedangkan hasil dari nilai keterampilan siswa dikategorikan cukup adalah 16 orang. Siswa dikategorikan baik adalah 4 orang dan siswa dikategorikan sangat baik adalah 14 orang. Dengan demikian indikator keberhasilan telah tercapai yaitu minimal $80 \%$.

Berdasarkan nilai hasil belajar yang diperoleh dan observasi aktivitas siswa dan observer menunjukkan peningkatan hasil belajar IPA yang sudah maksimal. Siswa sebanyak 32 
siswa telah memenuhi KKM yaitu 70 yang di tetapkan sedangkan 2 orang tidak memenuhi standar KKM dikarenakan kemampuan yang dimilikinya. Aktivitas siswa mengalami peningkatan secara maksimal. Sehingga peneliti dan observer sepakat untuk berhenti melanjutkan penelitian pada siklus selanjutnya.

\section{PEMBAHASAN}

Berdasarkan hasil pengamatan pada siklus I, siklus II dan siklus III dapat dilihat adanya peningkatan pada tiap siklusnya dengan menggunakan metode Teams Assisted Individualization dalam proses pembelajaran.

Hasil belajar dibagi dalam nilai pengetahuan, nilai keterampilan dan nilai sikap. Dapat dilihat dari hasil belajar siswa pada nilai pengetahuan memperoleh nilai rata-rata pra siklus adalah 55,14 dengan presentase ketuntasan $17,64 \%$ atau 6 siswa tuntas belajar dari 34 siswa. setelah diadakan siklus I diperoleh nilai rata-rata 58,38 dengan presentase $32,35 \%$ siswa yang tuntas belajar adalah 11 orang dari 34 siswa. pada siklus I sudah mulai memperhatikan penjelasan peneliti, namun siswa masih terbiasa belajar secara individu. Sehingga ketika melakukan diskusi kelompok dengan kelompoknya masih ada beberapa siswa yang ribut dan mengganggu teman kelompoknya. Ada beberapa siswa yang belum memahami materi yang diajarkan oleh peneliti. Sehingga pada siklus berikutnya perlu adanya perbaikan pada pengelolaan kelas dan cara penyampaian materi pelajaran oleh peneliti.

Setelah melaksanakan siklus II diperoleh nilai rata-rata siswa 70,73 dengan presentase ketuntasan 58,82\%. Pada siklus II siswa mulai aktif dalam diskusi kelompok. Walaupun mengalami peningkatan, tetapi hasil belajar siswa belum memenuhi indikator ketuntasan yaitu $80 \%$. Pada siklus II ini masih ada beberapa siswa yang perlu bimbingan peneliti dalam mengerjakan tugas yang diberikan oleh peneliti sehingga perlu adanya perbaikan pada siklus berikutnya.

Pada siklus III didapatkan nilai rata-rata 80,14 dengan presentase ketuntasan 94,11\%. Pada siklus III siswa sudah memahami metode yang digunakan dan siswa menyukai metode yang diterapkan oleh peneliti pada saat proses pembelajaran berlangsung. Diskusi kelompok juga berjalan dengan baik. Dengan demikian dapat dikatakan bahwa ketuntasan hasil belajar IPA kelas IV A SDN 010 Sungai Kunjang mengalami peningkatan.

Hasil belajar siswa pada nilai keterampilan juga mengalami peningkatan dengan menggunakan metode Teams Assisted Individualization. Berdasarkan hasil pengamatan yang dilakukan pada siklus I, siklus II, dan siklus III. Dapat dilihat dari hasil belajar nilai keterampilan pada siklus I siswa memperoleh nilai rata-rata 62,94 dengan presentase $35,29 \%$ pada siklus I sebagian siswa cukup baik dalam keterampilan menuliskan hasil diskusi mengenai metamorfosis sempurna dan tidak sempurna. Namun masih ada beberapa siswa yang kurang lengkap dalam menuliskan kesimpulan diskusinya. Sehingga perlu adanya perbaikan pada siklus berikutnya oleh peneliti yaitu dengan lebih membimbing siswa mengerjakan tugasnya.

Pada siklus II memperoleh nilai rata-rata 7,11 dengan presentase 70,58\%. Pada siklus II keterampilan siswa dalam membuat laporan hasil pengamatan sudah baik, beberapa siswa juga sudah bisa menuliskan laporan dengan rinci dan benar, walaupun pada siklus II telah mengalami peningkatan, tetapi hasil belajar belum mengalami materi yang diajarkan oleh peneliti. 
Sehingga pada siklus berikutnya perlu adanya perbaikan pada pengelolaan kelas dan cara penyampaian materi pelajaran oleh peneliti.

Setelah melakukan siklus II siswa mulai memahami metode dan materi yang diajarkan oleh peneliti. Pada siklus II ini siswa juga sudah mulai aktif dalam diskusi kelompok. Walaupun mengalami peningkatan, tetapi hasil belajar siswa belum memenuhi indikator ketuntasan yaitu 80\%. Pada siklus II ini masih ada beberapa siswa yang perlu bimbingan peneliti dalam mengerjakan tugas yang diberikan oleh peneliti sehingga perlu adanya perbaikan pada siklus berikutnya.

Pada siklus III didapatkan nilai rata-rata 8,14 dengan presentase $91,17 \%$, pada siklus III siswa sudah memahami metode yang digunakan dan siswa menyukai metode yang diterapkan oleh peneliti pada saat proses pembelajaran berlangsung. Diskusi kelompok juga berjalan baik. Dengan demikian dapat dikatakan bahwa ketuntasan hasil belajar siswa kelas IV

A Sungai Kunjang mengalami peningkatan.

Hasil belajar IPA pada nilai sikap juga mengalami peningkatan. Nilai sikap meliput sikap sosial dan sikap spiritual siswa. pada sikap spiritual meliputi perilaku bersyukur, kebiasaan berdo'a dan toleransi pada siklus I siswa dikategorikan baik adalah 19 Orang dan dikategorikan sangat baik adalah 15 orang. Pada siklus II sikap spiritual siswa yang memperoleh kategori baik adalah 16 Orang dan kategori sangat baik adalah 18 Orang. Pada siklus III siswa dikategorikan baik adalah 8 Orang dan kategori sangat baik adalah 26 Orang. Dengan demikian dapat dikatakan bahwa sikap spiritual siswa terjadi peningkatan yang baik pada setiap siklusnya.
Hasil belajar pada sikap sosial meliputi aspek jujur, disiplin, tanggung jawab, kerjasama, perduli dan percaya diri mengalami peningkatan. Dapat dilihat pada siklus I siswa dikategorikan baik adalah 32 orang dan kategori sangat baik adalah 2 Orang. Pada siklus II siswa dikategorikan baik adalah 18 orang dan sangat baik adalah 16 Orang. Pada siklus III semua 34 orang siswa dikategorikan sangat baik. Hal ini menunjukkan bahwa aspek sikap sosial siswa mengalami peningkatan yang baik pada setiap siklus.

$$
\text { Metode Teams Assisted }
$$

Individualization juga meningkatkan aktivitas belajar siswa. Pada siklus I aspek perhatian siswa dikategorikan cukup dengan presentase 64\%, disiklus I ini masih banyak siswa yang ribut dan tidak memperhatikan penjelasan peneliti. Pada siklus berikutnya peneliti melakukan perbaikan dengan peneliti merapikan tulisan saat menulis di papan tulis, labih sering mengontrol siswa saat mengerjakan latihan kemampuan, lebih sering mengawasi siswa saat berlangsungnya diskusi kelompok Pada siklus II aspek perhatian siswa dikategorikan baik dengan prsentase $70 \%$ hal ini menunjukkan adanya peningkatan, sudah banyak siswa yang mulai memperhatikan penjelasan peneliti ini dan mengerjakan tugas yang diberikan oleh peneliti. Pada siklus III aspek perhatian siswa mengalami peningkatan yaitu dikategorikan sangat baik dengan presentase $89 \%$, disiklus III ini siswa memperhatikan peneliti dan serius mengerjakan tugas yang diberikan oleh peneliti dengan baik dan benar.

Pada aspek keaktifan siswa siklus I dikategorikan cukup dengan presentase $65 \%$ disiklus I ini siswa kurang aktif dalam diskusi kelompok. Pada siklus II peneliti lebih memperhatikan pembagian kelompok dengan melihat siswa yang aktif dan 
tidak aktif dalam diskusi kelompok. Pada siklus II aspek keaktifan siswa dikategorikan baik dengan presentase $75 \%$ disiklus II siswa sudah mulai aktif dalam kelompok. Pada siklus III aspek keaktifan siswa dikategorikan sangat baik dengan presentase 93\% yang mana disiklus III ini siswa aktif berdiskusi dengan baik tanpa bimbingan peneliti. Dengan demikian terjadi peningkatan pada aspek keaktifan.

Pada aspek kerjasama siswa dikategorikan cukup dengan presentase $65 \%$ disiklus I ini siswa masih terbiasa mengerjakan tugas secara individu sehingga saat diskusi kelompok berlangsung masih ada beberapa siswa yang belum paham. Pada siklus berikutnya peneliti lebih menjelaskan lagi tanggung jawab siswa dalam kerjasama kelompok dan menyampaikan tujuan yang akan dicapai dalam diskusi kelompok tersebut. Pada siklus II aspek kerjasama siswa saat diskusi kelompok dikategorikan baik dengan presentase $69 \%$. Hal ini menunjukkan bahwa terjadi peningkatan aktivitas siswa. Pada aspek kerjasama siswa siklus III dikategorikan sangat baik dengan presentase $90 \%$ disiklus III siswa sangat antusias dalam mengikuti diskusi kelompok. Setiap siklus pada aspek kerjasama menunjukkan peningkatan.

Pada aspek pemahaman siswa pada siklus I dikategorikan cukup dengan presentase 69\%. Pada siklus I sebagian siswa sudah memahami materi dan tugas yang diberikan peneliti namun masih ada beberapa siswa yang kurang memahami penjelasan yang disampaikan peneliti. Oleh karena itu, perlu adanya perbaikan dalam penjelasan materi pembelajaran dan membimbing siswa yang belum memahami materi. Pada siklus II aspek pengetahuan siswa dikategorikan baik dengan presentase $74 \%$, pada siklus II ini sudah banyak siswa yang memahami tugas yang diberikan oleh peneliti. Pada siklus III pengetahuan siswa dikategorikan sangat baik dengan presentase $91 \%$, pada siklus III ini siswa mampu memahami tugas yang diberikan oleh peneliti dengan baik dan benar. Hal ini menunjukkan bahwa terjadi peningkatan pada aspek pengetahuan siswa setiap siklus.

Pada diagram diatas menunjukkan bahwa observasi siswa pada semua aspeknya terjadi peningkatan pada setiap siklus. Baik pada aspek perhatian siswa, keaktifan siswa, kerjasama siswa dan pengetahuan siswa.

Penelitian ini juga pernah dilakukan oleh Nikmah Lailatul pada tahun 2013 dengan judul "Penerapan metode TAI (Teams Assisted Individualization) untuk meningkatkan aktivitas dan hasil belajar IPA siswa kelas IV B SDN Candirenggo 04 Singosari Kabupaten Malang". Hasil penelitian ini menunjukkan adanya peningkatan setelah dilakukannya pembelajaran IPA menggunakan metode Teams Assisted Individualization dengan 2 siklus diperoleh hasil pada siklus I mencapai 79,55 dengan siswa yang tuntas sebanyak 14 siswa (70\%) dan siklus II mencapai 79,86 dengan siswa yang tuntas sebanyak 17 siswa (85\%). Hasil penelitian ini menunjukkan adanya peningkatan. Adapun penelitian yang peneliti yang dilakukan oleh peneliti adalah III siklus sedangkan penelitian di atas dilakukan II siklus dengan hasil belajar pada siklus terakhir (siklus II) $85 \%$. Sedangkan peneliti menggunakan III siklus dengan memperoleh hasil belajar pada siklus terakhir (siklus III) $94,11 \%$. Dengan ini menunjukkan bahwa metode Teams Assisted Individualization mampu meningkatkan hasil belajar siswa. 
Penelitian kedua dari Budianti, Vanny Maria dan Ratman pada tahun 2014 yang berjudul penerapan metode pembelajaran kooperatif tipe TAI (Teams Assisted Individualization) untuk meningkatkan hasil belajar mata pelajaran sains pada siswa kelas IV SDN 3 Labuan Panimba" . hasil penelitian menunjukkan bahwa pada tindakan siklus I diperoleh daya serap siswa $67 \%$ dengan ketuntasan klasikal $71 \%$ dan hasilnya ini meningkat pada tindakan siklus II yakni daya serap siswa mencapai $84 \%$ dengan ketuntasan belajar klasikal $84 \%$. Hal ini berarti pembelajaran pada siklus II telah memenuhi indikator keberhasilan yang telah ditetapkan dengan nilai daya serap individu minimal 65 serta ketuntasan belajar klasikal sudah mencapai indikator keberhasilan minimal $80 \%$. Adapun penelitian yang dilakukan oleh peneliti adalah III siklus sedangkan penelitian di atas dilakukan II siklus. Pada penelitian yang dilakukan oleh peneliti juga menunjukkan adanya peningkatan pada siklus I hasil belajar siswa memperoleh nilai rata-rata 58,38 dengan presentase $32,35 \%$, pada siklus II nilai rata-rata siswa 70,73 dengan presentase $58,82 \%$ dan siklus III nilai rata-rata 80,14 dengan presentase $94,11 \%$. Penelitian yang peneliti lakukan dengan penelitian sebelumnya mengalami peningkatan yang berbeda namun metode Teams Assisted Individualization dapat meningkatkan hasil belajar siswa.

Berdasarkan hasil evaluasi selama pelaksanaan siklus I, siklus II, dan siklus III, hasil tindakan yang diberikan peneliti selama pembelajaran IPA tentang daur hidup hewan melalui metode pembelajaran Teams Assisted Individualization yang diterapkan pada saat pembelajaran telah berhasil.

Kemudian penelitian tindakan ini telah sesuai dengan tujuan dan kelebihan dari teori Slavin (2016)
Teams Assisted Individualization (TAI) yaitu dapat membuat siswa bekerjasama antar kelompok dalam memecahkan masalah, membantu siswa yang kurang mampu secara akademik, meningkatkan pengetahuan siswa, meningkatkan kemampuan untuk menemukan konsep materi pembelajaran, memotivasi siswa dalam belajar kelompok serta meningkatkan hasil belajar siswa. serta adanya kemauan siswa yang bertambah meningkat dari siklus I ke siklus II dan siklus III, karena siswa pada saat pembelajaran semakin aktif.

\section{SIMPULAN}

Terdapat peningkatan hasil belajar IPA siswa dengan adanya peningkatan pada setiap siklusnya, yaitu siklus I dengan nilai rata-rata 48 dan ketuntasannya sebesar 29\%. Sedangkan pada siklus II dengan nilai rata-rata 70 dengan ketuntasan 58\%. Dan pada siklus III dengan nilai rata-rata 80 dan dengan ketuntasan 94\%, sehingga terjadi peningkatan dari siklus I, siklus II, dan siklus III. Adapun nilai keterampilan siswa yakni pada siklus I nilai rata-rat 62,94 dengan ketuntasan $35,29 \%$. Pada siklus II nilai rata-rata 7,11 dengan ketuntasan 70,58\% dan pada siklus III nilai rata-rata 8,14 dengan ketuntasan $91,17 \%$ serta nilai sikap yang meliputi sikap sosial dan sikap spiritual juga mengalami peningkatan setiap siklusnya. Dengan demikian dapat dikatakan metode Teams Assisted Individualization berhasil dalam meningkatkan hasil belajar IPA siswa.

Terdapat peningkatan keaktifan, perhatian, kerjasama dan pemahaman siswa disetiap siklusnya. Sehingga siswa semangat dan aktif belajar dengan metode Teams Assisted Individualization dan hasil belajar IPA siswa meningkat. 
DAFTAR PUSTAKA

Huda, M. (2013). Metode-Metode Pengajaran dan Pembelajaran. Pustaka Pelajar

Oemar, H. (2014). Proses Belajar Mengajar. Sinar Baru Algensindo

Rusman, R. (2011). Model-Model Pembelajaran Mengembangkan Profesionalisme Guru. Jakarta: PT. Rajagrafindo Persada

Sanjaya, . (2010). Pradigma Baru Mengajar. Original Segel

Shoimin, A. (2014). 68 Model Pembelajaran Inovatif dalam Kurikulum 2013. Yogyakarta: ArRuzz Media

Slavin, E. R. (2016). Cooperative Learning. Bandung: Nusa Media Sudjana, N. (2014). Penilaian Hasil Proses Belajar Mengajar. Rosda

Trianto, T. (2014). Mengembangkan Model Pembelajaran Tematik. Sukses Pustaka 